\title{
A nursing home staff tool for the indoor visual environment: The content validity
}

\author{
Marianne M. Sinoo ${ }^{* 1}$, Helianthe S.M. Kort ${ }^{1,2}$, Marcel G.L.C. Loomans ${ }^{2}$, Jos M.G.A. Schols ${ }^{3}$ \\ ${ }^{1}$ Utrecht University of Applied Sciences, Utrecht, The Netherlands \\ ${ }^{2}$ Eindhoven University of Technology, Eindhoven, The Netherlands \\ ${ }^{3}$ Caphri-School for Public Health and Primary Care, Maastricht University, Maastricht, The Netherlands
}

Received: January 14, 2016

DOI: $10.5430 /$ jnep.v6n $11 \mathrm{p} 25$
Accepted: May 30, 2016

Online Published: June 21, 2016

\begin{abstract}
In the Netherlands, over $40 \%$ of nursing home residents are estimated to have visual impairments. This results in the loss of basic visual abilities. The nursing home environment fits more or less to residents' activities and social participation. This is referred to as environmental fit. To raise professional awareness of environmental fit, an Environmental Observation tool for the Visually Impaired was developed. This tool targets aspects of the nursing home environment such as 'light', the use of 'colours and contrasts' and 'furnishing and obstacles'. Objective of this study is to validate the content of the observation tool to have a tool applicable for practice. Based on the content validity approach, we invited a total of eight experts, six eye care professionals and two building engineering researchers, to judge the relevance of the items. The Item Content Validity approach was applied to determine items to retain and reject. The content validity approach led to a decrease in the number of items from 63 to 52 . The definitive tool of 52 items contains 21 for Corridors, 17 for the Common Room, and 14 for the Bathroom. All items of the definite tool received an Item-Content Validity Index of $\geq 0.875$ and a Scale-Content Validity Index of $\geq 0.71$. The content validity index of the scale and per item has been applied, resulting in a tool that can be applied in nursing homes. The tool might be a starting point of a discussion among professional caregivers on environmental interventions for visually impaired older adults in nursing homes.
\end{abstract}

Key Words: Visual comfort, Nursing home, Environmental observation, Quality of life

\section{INTRODUCTION}

It is estimated that the population of older adults $(>65)$ in the Netherlands will increase from 3 million in the year 2015 to 4.2 million in $2030 .{ }^{[1]}$ Consequently, the group of institutionalised older adults in long-term care (158,000 in 2010) will grow up to $>350,000$ in 2050 . ${ }^{[2]}$ Low vision is very common among older adults. In the Netherlands, over $40 \%$ of nursing home residents are estimated to have visual impairments. ${ }^{[3]}$ Decreased visual functioning may even serve as a contributing factor to the nursing home placement of older adults. ${ }^{[4]}$

Visual impairments in nursing home residents due to cataracts, glaucoma, macular degeneration or diabetic retinopathy can result in the loss of basic visual abilities, such as visual acuity, contrast sensitivity and visual field loss. ${ }^{[5,6]}$ This may affect the quality of life of these residents by limiting their daily activities such as reading and restricting their participation in activities such as watching

\footnotetext{
*Correspondence: Marianne M. Sinoo; Email: marianne.sinoo@hu.nl; Address: Faculty of Health Care, Research Centre for Innovation in Health Care Heidelberglaan 7, 3584 CS Utrecht, The Netherlands.
} 
television and social interaction. ${ }^{[7]}$ In addition, earlier studies have shown that light conditions in the nursing home environment are poor. ${ }^{[8,9]}$ The nursing home environment might or might not facilitate residents' activities and participation.
This can be considered as the environmental fit, which this study describes using the framework of the International Classification of Functioning (ICF), published by the World Health Organisation ${ }^{[10]}$ as shown in figure 1.

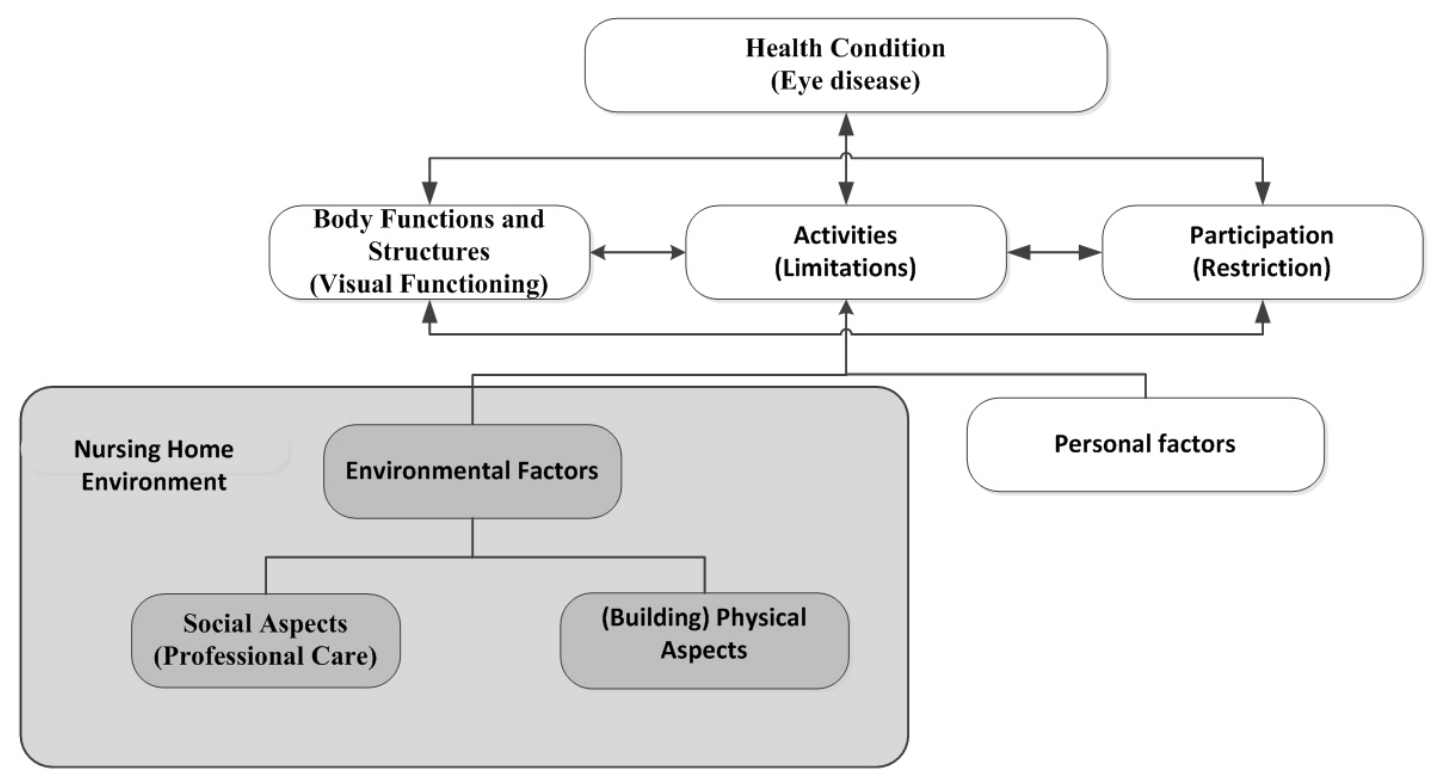

Figure 1. Shows the Interaction of the nursing home environment and nursing homes residents activities and participation, based on the ICF model ${ }^{[10]}$

In the centre of the ICF, the interaction of environmental factors, activities and participation of a resident with eye disease and affected visual functioning are shown. Environmental factors consist of social aspects or (building) physical aspects such as light (e240). Creating a healthy (visual) environment for nursing home residents is one of the tasks of professional caregivers in nursing homes. ${ }^{[11]}$ As an environmental factor in the ICF model, professional caregivers themselves may improve the living environment by controlling light conditions, the use of colours and contrasts, and the arrangement of spaces. ${ }^{[8,12-14]}$

The importance of awareness of nursing home residents' visual functioning has been addressed by former studies. $^{[6,13-16]}$

A supporting tool might raise professional caregivers' awareness of these environmental factors, indicated as (building) physical aspects in Figure 1. In a pilot study, ${ }^{[17]}$ the content and layout of the Environmental Observation tool for the Visually Impaired (EOVI-63) was determined by use of a literature search and open observations in seven nursing homes.The tool was developed because previous studies howed that nursing homes had poor light conditions and because of professional caregivers' lack of awareness of these light conditions and their effect on the residents. ${ }^{[15,16]}$ The tool targets indoor light related aspects of the nursing home environment, such as quality of light, the use of colours \& contrasts and furnishing \& obstacles, to prevent residents from falling. These aspects concern items in common rooms, corridors and bathrooms in nursing homes. From a practical point of view, and keeping the workload of professional caregivers in mind, the tool should contain a minimum number of items. In a pilot study, the observers needed 12-23 minutes to complete all the items. ${ }^{[17]}$

The aim of the EOVI is to serve as a tool to observe light related aspects in nursing homes for interprofessional discussion about building physical aspects and visual functioning. This, to contribute to raise awareness of aspects of environmental fit. Therefore, only indoor environmental items that could be observed by professional caregivers without the use of any device have been adopted.

\section{Aim of the study}

To validate the content of the observation tool in order to have a tool applicable for interprofessional discussions.

\section{METHOD}

In the pilot study, the face validity of the first version of the EOVI with 63 items (EOVI-63) was formulated and judged as relevant by colleague researchers in eye care and building 
engineering. Furthermore, agreement was reached on the content of the EOVI-63, structured into the following environmental aspects: light, colour \& contrast, and furnishing $\&$ obstacles. The items were judged for all three parameters of common rooms $(\mathrm{n}=25$ items), corridors $(\mathrm{n}=23$ items), and bathrooms ( $\mathrm{n}=15$ items) of a nursing home ward. Private rooms were excluded because they are furnished according to the taste and wishes of the resident or his/her family. In this study, the content validity of the EOVI-63 is tested.

\subsection{Content validity}

Content validity refers to "the sampling adequacy of items for the construct that is being measured". ${ }^{[18]}$ According to Polit and Beck, ${ }^{[19]}$ "content validity concerns the degree to which a scale has an appropriate sample of items to represent the construct of interest". It is typically measured by the Content Validity Index (CVI). The CVI is based on the judgement of experts in the field of interest. The role of the experts is to advise the researcher concerning the relevance and formulation of the items. According to Polit, Beck, and Owen, ${ }^{[20]}$ there are three ways to determine the CVI: The proportion of relevant items per expert (E-CVI); the proportion based on the number of agreements per item (I-CVI), and the Scale Universal Agreement as the number of items rated relevant by all experts (S-CVI-UA). In this study, we focus on the item quality. Therefore, the I-CVI and the S-CVI-UA are used to establish the content validity of the EOVI.

In the content validity approach of Polit and Beck, ${ }^{[19]}$ and Lynn, ${ }^{[21]}$ it is advised to invite at least seven experts but no more than ten. In this study, we invited a total of eight experts from our research and educational network: Six professional eye care experts and two researchers in the built environment. The experts were chosen because of their different specific knowledge in the fields of eye care and the built environment $(2,7)$. The six professionals in eye care were an optician $(1)$, a low vision specialist (6), an ophthalmologist (8), and three members of an assessment team of Bartimeus $(3,4,5)$. This assessment team screens residents' (upon the request of a nursing home) on visual functioning and provides further referrals for ophthalmological consultation and rehabilitation possibilities. Bartimeus is a national expert centre that aims to improve the quality of life of the blind and visually impaired (www.bartimeus.nl). Screening of nursing home residents is one of its tasks, and in future assessments, it might even use the EOVI as a tool to raise nursing home care professionals' environmental awareness.

\subsection{Analysis}

To validate the content of the EOVI-63, the Item-Content Validity Index (I-CVI) and the Scale-Content Validity Index of Universal Agreement (S-CVI UA) were computed. [19]

All eight experts were asked to judge the relevance of the items of the EOVI- 63 on a 4-point rating scale ( $1=$ highly relevant, $2=$ relevant, $3=$ slightly relevant, $4=$ not relevant). In the results, scores 1 and 2 are considered as relevant (x) and scores 3 and 4 as not relevant (-). The (I-CVI) for each item was computed as the number of experts who judged the item as relevant $(\mathrm{x})$ divided by the total number of experts.

$$
I-C V I=\sum \frac{I_{x}}{n_{\text {etot }}}
$$

$I_{x}=$ number of experts judging the item as 1.00 (relevant), $n_{\text {etot }}=$ total number of experts

If all items are considered relevant by the experts, the I-CVI $=1.00$. According to the guidelines, ${ }^{[19,21]}$ an I-CVI $\geq 0.875$ is considered to be the minimum agreement for eight experts, resulting in the removal of all items with a score $<0.875$ from the EOVI-63.

Furthermore, the Scale-Content Validity Index of Universal Agreement (S-CVI UA) was computed for the subscales (s) Corridors, Common Room, and the Bathroom as the number of items rated as an I-CVI of 1.00 [all the experts judged the item as relevant (x)] divided by the total number of items.

$$
S-C V I-U A=\sum \frac{I_{1.00}}{n_{i t o t}}
$$

$I_{1.00}=$ items judged as 1.00 (relevant), $n_{i t o t}=$ total number of items.

Additional textual comments on the items were processed by the first author. The changed items were resubmitted for approval to all experts in a second round. If seven or more of the eight experts agreed on the changed item, it was changed. This resulted in a definite version of the EOVI, called the EOVI-52.

A translated version of the EOVI-63 was needed for international publication. Therefore, a translation-retranslation (i.e., Dutch-English-Dutch) was performed, resulting in English and Dutch versions of the EOVI. However, in the content validity process, the experts judged only the items of the Dutch version.

\section{Results}

All eight experts judged the relevance of the 63 items of the first version of the EOVI. Table 1 shows the results of the experts' opinions about the 38 proposed items for the Corridors (23 items). 
Table 1. Content validation of the Environmental Observation tool for the Visually Impaired EOVI-63 for Corridors (23 items)

\begin{tabular}{|c|c|c|c|c|c|c|c|c|c|}
\hline EXPERTS & 1 & 2 & 3 & 4 & 5 & 6 & 7 & 8 & \\
\hline \multicolumn{10}{|l|}{ CORRIDORS n = 23 items } \\
\hline LIGHT & & & & & & & & & I-CVI \\
\hline $\begin{array}{l}\text { 1. The lamps provide bright white light. } \\
\text { (Colours appear natural.) }\end{array}$ & $\mathrm{x}$ & $\mathrm{x}$ & $\mathrm{x}$ & $\mathrm{x}$ & $\mathrm{x}$ & $\mathrm{x}$ & - & $\mathrm{x}$ & 0.875 \\
\hline $\begin{array}{l}\text { 2. The lamps provide uniform illumination. } \\
\text { (There is no sudden transition from light to dark.) }\end{array}$ & $\mathrm{x}$ & $\mathrm{x}$ & $\mathrm{x}$ & $\mathrm{x}$ & $\mathrm{x}$ & $\mathrm{x}$ & $\mathrm{X}$ & $\mathrm{x}$ & 1.00 \\
\hline 3. The walls are light in colour. & $\mathrm{x}$ & $\mathrm{x}$ & $\mathrm{x}$ & $\mathrm{x}$ & $\mathrm{x}$ & $\mathrm{x}$ & $\mathrm{x}$ & $\mathrm{x}$ & 1.00 \\
\hline 4. The floors are light in colour. & $\mathrm{x}$ & $\mathrm{x}$ & - & - & $\mathrm{x}$ & $\mathrm{x}$ & $\mathrm{x}$ & $\mathrm{x}$ & 0.75 \\
\hline $\begin{array}{l}\text { 5. Paintings are placed ensuring that light reflection and glare } \\
\text { is prevented. }\end{array}$ & $\mathrm{x}$ & - & $\mathrm{x}$ & $\mathrm{x}$ & $\mathrm{x}$ & $\mathrm{x}$ & $\mathrm{x}$ & $\mathrm{x}$ & 0.875 \\
\hline $\begin{array}{l}\text { 6. At each window, bright light can be sufficiently shielded. } \\
\text { (Drapes or blinds are functional.) }\end{array}$ & $\mathrm{x}$ & $\mathrm{x}$ & $\mathrm{x}$ & $\mathrm{x}$ & $\mathrm{x}$ & $\mathrm{x}$ & $\mathrm{x}$ & $\mathrm{x}$ & 1.00 \\
\hline $\begin{array}{l}\text { 7. Lighting is not only decorative, but specifically illuminates } \\
\text { the floor. }\end{array}$ & $\mathrm{x}$ & $\mathrm{x}$ & $\mathrm{x}$ & $\mathrm{x}$ & $\mathrm{x}$ & $\mathrm{x}$ & - & $\mathrm{x}$ & 0.875 \\
\hline 8. The floor and walls are matte. (not shiny). & $\mathrm{x}$ & $\mathrm{x}$ & $\mathrm{x}$ & $\mathrm{x}$ & $\mathrm{x}$ & $\mathrm{x}$ & $\mathrm{x}$ & $\mathrm{x}$ & 1.00 \\
\hline \multicolumn{10}{|l|}{ COLOUR \& CONTRAST } \\
\hline 9. The flooring is of one colour. (uniform, with no wild print). & $\mathrm{x}$ & $\mathrm{x}$ & $\mathrm{x}$ & $\mathrm{x}$ & $\mathrm{x}$ & $\mathrm{x}$ & $\mathrm{x}$ & $\mathrm{x}$ & 1.00 \\
\hline 10. The wall covering is one colour. & $\mathrm{x}$ & - & $\mathrm{x}$ & $\mathrm{x}$ & $\mathrm{x}$ & $\mathrm{x}$ & $\mathrm{x}$ & $\mathrm{x}$ & 0.875 \\
\hline $\begin{array}{l}\text { 11. The colours of the floor and walls are contrasting. } \\
\text { (The floor is darker than the walls.) }\end{array}$ & $\mathrm{x}$ & $\mathrm{x}$ & $\mathrm{x}$ & $\mathrm{X}$ & - & $\mathrm{x}$ & $\mathrm{X}$ & $\mathrm{X}$ & 0.875 \\
\hline $\begin{array}{l}\text { 12. The hand railing on the wall is clearly visible. } \\
\text { (The colour of the handrail contrasts with the background.) }\end{array}$ & $\mathrm{x}$ & $\mathrm{x}$ & $\mathrm{x}$ & $\mathrm{X}$ & $\mathrm{x}$ & $\mathrm{x}$ & $\mathrm{x}$ & $\mathrm{x}$ & 1.00 \\
\hline $\begin{array}{l}\text { 13. Doorsteps are clearly marked across their full width using a } \\
\text { striking colour }\end{array}$ & $\mathrm{x}$ & $\mathrm{x}$ & $\mathrm{x}$ & $\mathrm{x}$ & $\mathrm{x}$ & $\mathrm{x}$ & $\mathrm{x}$ & $\mathrm{x}$ & 1.00 \\
\hline $\begin{array}{l}\text { 14. Glass doors are clearly marked with a strip at eye/chest } \\
\text { height. }\end{array}$ & - & $\mathrm{x}$ & $\mathrm{x}$ & $\mathrm{X}$ & $\mathrm{x}$ & $\mathrm{x}$ & $\mathrm{x}$ & $\mathrm{X}$ & 0.875 \\
\hline 15. Signs and icons are situated at, or just above, eye level. & $\mathrm{x}$ & $\mathrm{x}$ & $\mathrm{x}$ & $\mathrm{x}$ & $\mathrm{x}$ & $\mathrm{x}$ & $\mathrm{x}$ & $\mathrm{x}$ & 1.00 \\
\hline $\begin{array}{l}\text { 16. The letters on signs and icons are large. } \\
\text { (and easily legible for all residents). }\end{array}$ & $\mathrm{x}$ & - & $\mathrm{x}$ & $\mathrm{x}$ & $\mathrm{x}$ & $\mathrm{x}$ & $\mathrm{x}$ & $\mathrm{x}$ & 0.875 \\
\hline $\begin{array}{l}\text { 17. The colours used in icons and letters on signs are easy to } \\
\text { distinguish. }\end{array}$ & $\mathrm{x}$ & $\mathrm{x}$ & $\mathrm{x}$ & $\mathrm{x}$ & $\mathrm{x}$ & $\mathrm{x}$ & $\mathrm{x}$ & $\mathrm{x}$ & 1.00 \\
\hline 18. The house number and nameplate are easily legible. & $\mathrm{x}$ & - & $\mathrm{x}$ & $\mathrm{x}$ & $\mathrm{x}$ & $\mathrm{x}$ & - & $\mathrm{x}$ & 0.75 \\
\hline 19. There is a light within the call button. & $\mathrm{x}$ & $\mathrm{x}$ & $\mathrm{x}$ & $\mathrm{x}$ & $\mathrm{x}$ & $\mathrm{x}$ & $\mathrm{x}$ & $\mathrm{x}$ & 1.00 \\
\hline $\begin{array}{l}\text { 20. The door handle and door frames can be easily } \\
\text { distinguished by colour and contrast. }\end{array}$ & $\mathrm{x}$ & $\mathrm{x}$ & $\mathrm{x}$ & $\mathrm{x}$ & $\mathrm{x}$ & $\mathrm{x}$ & $\mathrm{x}$ & $\mathrm{x}$ & 1.00 \\
\hline \multicolumn{10}{|l|}{ FURNISHING \& OBSTACLES } \\
\hline $\begin{array}{l}\text { 21. All obstacles are situated on one side of the corridor. } \\
\text { (Such as fire extinguishers, hoists, medication table, } \\
\text { wheelchairs and walking frames). }\end{array}$ & $\mathrm{x}$ & $\mathrm{x}$ & $\mathrm{x}$ & $\mathrm{x}$ & $\mathrm{x}$ & $\mathrm{X}$ & $\mathrm{x}$ & $\mathrm{x}$ & 1.00 \\
\hline 22. The house number and nameplate are placed at eye level. & $\mathrm{x}$ & $\mathrm{x}$ & $\mathrm{x}$ & $\mathrm{x}$ & $\mathrm{x}$ & $\mathrm{x}$ & - & $\mathrm{x}$ & 0.875 \\
\hline 23. There is plenty of room to move. & $\mathrm{X}$ & $\mathrm{x}$ & $\mathrm{x}$ & $\mathrm{x}$ & $\mathrm{x}$ & $\mathrm{x}$ & $\mathrm{x}$ & $\mathrm{x}$ & 1.00 \\
\hline
\end{tabular}

Note. I-CVI $=$ Content Validity Index per Item $(\geq 0.875$ item is maintained $)$

$\mathrm{x}=$ highly relevant or relevant; $-=$ slightly relevant or not relevant

Experts: 1 = optician, 2 = building engineer, $3,4,5$ assessment team visual functioning in nursing homes, $6=$ Low vision specialist, $7=$ building engineer, $8=$ ophthalmologist The bold I-CVI values are NOT considered relevant by two or more experts.

The I-CVI scores of the Corridors in Table 1 show that two of the 23 items (item 4: "The floors are light in colour" and item 18: "The house number and name plate are easily legible") are not considered "highly relevant or relevant" by two of the experts. Accordingly, these items are removed, resulting in 21 items for the Corridors. All experts endorsed thirteen of the Corridor items (I-CVI $=1.00$ ). The S-CVI UA with all Corridor items maintained is $0.52(13 / 23)$. However, when the Corridor items of an I-CVI $<0.875$ are deleted, the S-CVI UA is $12 / 17=0.71$. 
In Table 2, the results of the experts' opinions about the 25 proposed items for the Common Room are shown.

Table 2. Content validation of the Environmental Observation tool for the Visually Impaired EOVI-63 for Common Room

\begin{tabular}{lllllllllll}
\hline EXPERTS & 1 & 2 & 3 & 4 & 5 & 6 & 7 & 8 & \\
\hline
\end{tabular}

COMMON ROOM n= 25 items

\section{LIGHT}

24. Windows provide even room lighting.

(There is no transition from dark to light.)

25. The lamps provide bright white light.

(Colours appear natural.)

26. Activities are illuminated from behind the resident.

27. During residents' activities, lighting can be adjusted for each individual.

28. There is extra lighting at the tables and chairs to enable activities such as reading.

29. At each window, bright light can be sufficiently shielded.

(Drapes or blinds are functional.)

30. The tabletops or worktops are matte. (not shiny).

31. The mirrors and paintings framed under glass are placed ensuring that light reflection and glare are prevented.

32. Chairs and other seating are near a window (where possible).

33. It is possible to sit close to the television.

\section{COLOUR \& CONTRAST}

34. There is difference in colour between the flooring in the living room and in the corridor.

35. The clock is clearly legible.

(The hands and the numbers contrast with the background and are large enough.)

36. The chairs have a contrasting colour to the floor.

37. The door handle and door frames can be distinguished by colour contrast.

38. The switches and sockets contrast in colour with the wall and are at a reachable height.

39. All the characters are at eye level and large/contrasting.

40. Electrical wires or leads are concealed or have a contrasting colour to the wall and floor.

41. The chairs have a contrasting colour to the floor.

42. The tables have a contrasting colour to the floor.

43. Upon laying the table, placemats or tablecloths used are plain in colour.

44. Upon laying the table, the use of contrasting colours is taken into account.

\section{FURNISHING \& OBSTACLES}

45. All corners on furniture are rounded.

46. There are no protruding objects, including drawers or doors left (half) open.

47. Doorsteps are marked across their full width with a line in a striking colour.

48. There is plenty of room to move.
I-CVI

0.75

1.00

0.75

0.75

0.875

0.625

0.75

0.875

1.00

1.00

1.00

0.875

0.75

0.75

1.00

$\begin{array}{llllllllll}\mathrm{x} & \mathrm{x} & \mathrm{x} & \mathrm{x} & \mathrm{x} & \mathrm{x} & \mathrm{x} & - & 0.875\end{array}$

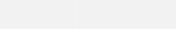

\begin{tabular}{lcccccccc}
$\mathrm{x}$ & - & - & $\mathrm{x}$ & $\mathrm{x}$ & $\mathrm{x}$ & $\mathrm{x}$ & $\mathrm{x}$ & $\mathbf{0 . 7 5}$ \\
$\mathrm{x}$ & $\mathrm{x}$ & $\mathrm{x}$ & $\mathrm{x}$ & $\mathrm{x}$ & $\mathrm{x}$ & $\mathrm{x}$ & $\mathrm{x}$ & 1.00 \\
$\mathrm{x}$ & $\mathrm{x}$ & $\mathrm{x}$ & $\mathrm{x}$ & $\mathrm{x}$ & $\mathrm{x}$ & $\mathrm{x}$ & $\mathrm{x}$ & 1.00 \\
$\mathrm{x}$ & $\mathrm{x}$ & $\mathrm{x}$ & $\mathrm{x}$ & $\mathrm{x}$ & $\mathrm{x}$ & $\mathrm{x}$ & $\mathrm{x}$ & 1.00 \\
\hline
\end{tabular}

Note. I- CVI $=$ Content Validity Index per Item $(\geq 0.875$ item is maintained $)$

$\mathrm{x}=$ highly relevant or quite relevant; $-=$ slightly relevant or not relevant

Experts: 1 = optician, 2 = building engineer, 3,4,5 assessment team visual functioning in nursing homes, $6=$ Low vision specialist, $7=$ building engineer, $8=$ ophthalmologist.

The bold I-CVI values are NOT considered relevant by two or more experts. 
The I-CVI scores in Table 2 show that eight of the 25 Com- (I-CVI = 1.00). The S-CVI UA with all Common Room mon Room items are not considered "highly relevant or relevant" by two or more of the experts. Accordingly, items 41, 46, 47, 49, 50, 56, 57 and 60 are removed, resulting in 17 items for the Common Room.

items maintained is $0.48(12 / 25)$. When the items of an I-CVI $<0.875$ are deleted, the S-CVI UA is $12 / 17=0.71$.

Table 3 shows the results of the experts' opinions about the 38 proposed items for the Bathroom (15 items).

All experts endorsed twelve out of all Common Room items

Table 3. Content validation of the Environmental Observation tool for the Visually Impaired EOVI-63 for Bathroom (15 items)

\begin{tabular}{|c|c|c|c|c|c|c|c|c|c|}
\hline Experts & 1 & 2 & 3 & 4 & 5 & 6 & 7 & 8 & \\
\hline \multicolumn{10}{|l|}{ BATHROOM n = 15 items } \\
\hline LIGHT & & & & & & & & & I-CVI \\
\hline 49. Mirrors and tiles do not cause blinding glare (by reflection). & $\mathrm{x}$ & $\mathrm{x}$ & $\mathrm{x}$ & $\mathrm{x}$ & $\mathrm{x}$ & $\mathrm{x}$ & $\mathrm{x}$ & $\mathrm{x}$ & 1.00 \\
\hline $\begin{array}{l}\text { 50. The lamps provide bright white light. } \\
\text { (Colours appear natural.) }\end{array}$ & $\mathrm{x}$ & $\mathrm{x}$ & $\mathrm{x}$ & $\mathrm{x}$ & $\mathrm{x}$ & $\mathrm{x}$ & $\mathrm{x}$ & $\mathrm{x}$ & 1.00 \\
\hline \multicolumn{10}{|l|}{ COLOUR \& CONTRAST } \\
\hline $\begin{array}{l}\text { 51. The colour used for the floor is different from that of the walls. } \\
\text { (The floor is darker than the walls.) }\end{array}$ & $\mathrm{x}$ & $\mathrm{x}$ & $\mathrm{x}$ & $\mathrm{x}$ & - & $\mathrm{x}$ & $\mathrm{x}$ & $\mathrm{x}$ & 0.875 \\
\hline $\begin{array}{l}\text { 52. Doorsteps are marked across their full width with a line in a striking } \\
\text { colour. }\end{array}$ & $\mathrm{x}$ & $\mathrm{x}$ & $\mathrm{x}$ & $\mathrm{x}$ & - & $\mathrm{x}$ & $\mathrm{x}$ & $\mathrm{x}$ & 0.875 \\
\hline 53. The hand railing on the wall is clearly visible. & $\mathrm{x}$ & $\mathrm{x}$ & $\mathrm{x}$ & $\mathrm{x}$ & $\mathrm{x}$ & $\mathrm{x}$ & $\mathrm{x}$ & $\mathrm{x}$ & 1.00 \\
\hline $\begin{array}{l}\text { 54. The door handle and door frames can be distinguished by colour and } \\
\text { contrast }\end{array}$ & $\mathrm{x}$ & $\mathrm{x}$ & $\mathrm{x}$ & $\mathrm{x}$ & $\mathrm{x}$ & $\mathrm{x}$ & $\mathrm{x}$ & $\mathrm{x}$ & 1.00 \\
\hline 55. The colour of the towels contrasts with the bathroom interior. & $\mathrm{x}$ & $\mathrm{x}$ & $\mathrm{x}$ & $\mathrm{x}$ & $\mathrm{x}$ & $\mathrm{x}$ & $\mathrm{x}$ & - & 0.875 \\
\hline $\begin{array}{l}\text { 56. The colour of the toilet seat contrasts with the colour of the toilet and } \\
\text { bathroom interior }\end{array}$ & $\mathrm{x}$ & $\mathrm{x}$ & $\mathrm{x}$ & $\mathrm{x}$ & $\mathrm{x}$ & $\mathrm{x}$ & $\mathrm{x}$ & $\mathrm{x}$ & 1.00 \\
\hline 57. The colour of the toilet roll holder contrasts with the toilet paper. & $\mathrm{x}$ & $\mathrm{x}$ & $\mathrm{x}$ & $\mathrm{x}$ & $\mathrm{x}$ & $\mathrm{x}$ & $\mathrm{x}$ & $\mathrm{x}$ & 1.00 \\
\hline 58. The hot and cold water taps are labelled clearly. & $\mathrm{x}$ & $\mathrm{x}$ & $\mathrm{x}$ & $\mathrm{x}$ & $\mathrm{x}$ & $\mathrm{x}$ & $\mathrm{x}$ & $\mathrm{x}$ & 1.00 \\
\hline $\begin{array}{l}\text { 59. The accessories situated on the floor are clearly visible compared to the } \\
\text { walls and floors, such as a laundry basket. }\end{array}$ & $\mathrm{x}$ & $\mathrm{x}$ & $\mathrm{x}$ & $\mathrm{x}$ & $\mathrm{x}$ & $\mathrm{x}$ & $\mathrm{x}$ & $\mathrm{x}$ & 1.00 \\
\hline 60. The light buttons and alarm bells are clearly visible. & $\mathrm{x}$ & $\mathrm{x}$ & $\mathrm{x}$ & $\mathrm{x}$ & $\mathrm{x}$ & $\mathrm{x}$ & $\mathrm{x}$ & $\mathrm{x}$ & 1.00 \\
\hline \multicolumn{10}{|l|}{ FURNISHING \& OBSTACLES } \\
\hline 61. There are anti-slip mats or tiles with structure. & $\mathrm{x}$ & $\mathrm{x}$ & $\mathrm{x}$ & $\mathrm{x}$ & $\mathrm{x}$ & $\mathrm{x}$ & $\mathrm{x}$ & $\mathrm{x}$ & 1.00 \\
\hline 62. The sinks have rounded edges. & $x$ & - & - & $x$ & $x$ & $x$ & $x$ & $\mathrm{x}$ & 0.75 \\
\hline 63. Steps and doorsteps are clearly marked. & $\mathrm{x}$ & $\mathrm{x}$ & $\mathrm{x}$ & $\mathrm{x}$ & $\mathrm{x}$ & $\mathrm{x}$ & $\mathrm{x}$ & $\mathrm{x}$ & 1.00 \\
\hline
\end{tabular}

Note. $\mathrm{I}$-CVI $=$ Content Validity Index per Item $(\geq 0.875$ item is maintained $)$

$\mathrm{x}=$ highly relevant or relevant; - = slightly relevant or not relevant

Experts: 1 = optician, $2=$ building engineer, $3,4,5$ assessment team visual functioning in nursing homes, $6=$ Low vision specialist, $7=$ building engineer, $8=$ ophthalmologist The bold I-CVI values are NOT considered relevant by two or more experts.

The I-CVI scores of the 15 Bathroom items show that only one item is not considered "highly relevant or relevant" by two experts. Accordingly, item 37: "The sinks have rounded edges" is removed, resulting in 14 items for Bathroom. All experts endorsed eleven Bathroom items. The S-CVI UA with all bathroom items maintained is $0.73(11 / 15)$. When the bathroom items with an I-CVI $<0.875$ are deleted, the S-CVI UA is $11 / 14=0.79$.

\section{Discussion}

In this study the emphasis was on the content validity of the EOVI-63. Eight experts in either eye care or building engineering established the content validity of the EOVI-63. As a result, 11 of the 63 items were deleted from the first version of the tool, resulting in the EOVI-52.

The interaction of eye disease, visual functioning and envi- 
ronmental factors with activities and participation of nursing home residents can be addressed with ICF. In ICF, environmental factors consist of social aspects or (building) physical aspects. This is in congruence with the Home assessment of Person-Environment Interaction (HoPE) instrument, which was developed for offices. ${ }^{[22]}$ Here, professional caregivers are described as part of the 'human environment' and distinguished from the 'non-human environment'. In ICF, the 'human environment' is described as 'social aspects' and the 'non-human environment' as 'building physical aspects'.

Only a few tools have been developed to target the environment of visually impaired older adults. ${ }^{[23]}$ These tools are specific in addressing one or two components such as light and the use of colour and contrast or the use of technical devices. The items of the EOVI are partially based on the EVOLVE tool of Lewis and Torrington, ${ }^{[24]}$ a checklist for extra care-housing for people with sight loss, and the homebased assessment tool validated by Carignan, Rousseau, and Couturier. ${ }^{[23]}$

In the EOVI-63, "Furnishing \& Obstacles" is added as an extra aspect because of the risk of falling. ${ }^{[25]}$ The experts in this study considered these items to be relevant.

During the content validity process, some experts discussed the use of layman terminology in the EOVI instead of professional building engineering terminology (e.g., reducing glare by "sun blinds" instead of using the term "a brightness controlling system"). According to the aim of the EOVI, we decided to use layman terminology instead of building engineering terminology.

Another limitation of the study might be that only the content validity of the Dutch version of the EOVI tool was tested. However, we expect that experts of different countries use the same body of knowledge and would judge the same items as relevant or not relevant. Only a study in an English-speaking country can confirm this assumption. However, such a study is not within the scope of the current study.

Furthermore, the English version and the Dutch version should be tested in practice to prove their support in raising the environmental awareness of care professionals. The tool might be a starting point for the discussion among professional caregivers of environmental interventions for visually impaired older adults in nursing homes.

Determination of content validity is based on the judgement and reasoning of the researcher which is validated by an expert panel. In future research the construct validity of the EOVI could be determined by obtaining objective measuremnets in a controlled setting.

Published by Sciedu Press

\subsection{Appraisal of the I-CVI}

Polit, Beck, and Owen ${ }^{[20]}$ discuss the acceptability of the I-CVI as an indicator of content validity. They state that the I-CVI shows advantages, as it focuses on the agreement of relevance and consensus of experts rather than on agreement per se. However, they criticise the I-CVI for the absence of an adjustment for chance. They state that "the I-CVI captures inter-rater agreement but not full inter-rater agreement". It is considered as a weakness that a 4-point rating scale is transferred into two categories of relevant $(\mathrm{X})$ and not relevant (-) items. However, Polit, Beck, and Owen ${ }^{[20]}$ propose an adjustment of I-CVI values for three to nine experts. They make an adjustment of the I-CVI for chance agreement $\left(\mathrm{k}^{*}\right)$ and propose the evaluation criteria of 'fair', 'good' or 'excellent' for $\mathrm{k}^{*}$ with eight experts. The I-CVI values of 1.00 and 0.875 , found in this study with eight experts, are both evaluated as 'excellent'. The I-CVI value of 0.75 has a $\mathrm{k}^{*}$ value of 0.72 and is evaluated as 'good'. ${ }^{[20]}$ Nevertheless, we even excluded these items to reduce the number of items of the EOVI.

\subsection{The number of experts included}

In the content validation literature, a minimum of five is proposed as a sufficient level of control for chance agreement. ${ }^{[20,21]}$ The determination of the number of experts is somewhat arbitrary but depends on the content domain areas. In this study, the domain areas were vision, eye care and building engineering, but more eye care experts than building engineers were invited to evaluate the items of the EOVI. The reason for this difference in number of experts is that different eye care professionals (ophthalmologist, optician, optometrist, orthoptist, and low vision specialist) are involved in eye care services for nursing home residents in the Netherlands. Even so, the inclusion of the Bartimeus assessment team was important from a practical point of view. In future eye assessments in nursing homes, they might use the EOVI-52 as a tool to raise awareness concerning nursing homes' quality of light, use of colour \& contrast and furnishing \& obstacles.

Within the ICF model, the EOVI, consisting of 52 validated items, can be seen as an interacting tool between social and building physical aspects of the nursing home environment. Since the content validation of the EOVI is established, the tool is ready for a complete validation study in a robust and diverse sample.

\section{Conclusions}

Eight experts in the field of eye care and building engineering validated the content of the EOVI-63. The content validity approach led to a decrease in the number of items from 63 
to 52. The 52 items of the EOVI-52 consist of 21 items for the Corridors, 14 for the Bathroom, and 17 for the Common Room. The items represent the aspects Light, Colour \& Contrast, and Furnishing \& Obstacles. All remaining items received a rating of "highly relevant or relevant" from at least seven of the eight experts, making the I-CVI rating for each item $\geq 0.875$. The EOVI-52 will be more applicable for practice due to the established content validity and the reduction in items.

\section{Practical implications}

The tool might be used as a starting point for the discussion among professional caregivers of environmental interventions for visually impaired older adults in nursing homes.
Care professionals can use the EOVI tool (Download the EOVI in English or Dutch at: http://www.onderzoek. hu.nl/onderzoekers/marianne-sinoo) to identify and discuss light conditions, the use of colour and contrasts, and the furnishing of the ward.

\section{ACKNOWLEDGEMENTS}

We thank S. Mueller Schotte, M. Aarts, L. van den Bosch, M. van Egmond, P. Hardus, G. Koevoets, M. Loomans, and A. Verezen for their cooperation in the content validation process. We thank I. Wittering and J. Reinten for their help with the translation-retranslation of the EOVI.

\section{CONFLICTS OF INTEREST DisClOSURE}

The authors declare that they have no conflicts of interest.

\section{REFERENCES}

[1] CBS Prognose bevolking; kerncijfers 2011-2060 [in Dutch] http://statline.cbs.nl/Statweb/publication/?DM=SLNL $\& P A=81411$ ned\&D1 $=2-3,5-6 \& D 2=0-$ [accessed 4 January 2016]

[2] ten Draak M. Oudere tehuisbewoners; landelijk overzicht van de leefsituatie van ouderen in instituties. 2008/2009. Den Haag: SCP; 2010. [In Dutch]. http://www.scp.nl/Publicaties/Alle_pu blicaties/Publicaties_2010/Oudere_tehuisbewoners

[3] Limburg HJEE, van Keunen JEE. Blindness and low vision in The Netherlands from 2000 to 2020-modeling as a tool for focused intervention. Ophthalmic Epidemiology. 2009; 16(6): 362 369. PMid:19995201. http://dx.doi.org/10.3109/0928658 0903312251

[4] Wang JJ, Mitchell P, Cumming RG, et al. Blue Mountains Eye Study. Visual impairment and nursing home placement in older Australians: the Blue Mountains Eye Study. Ophthalmic Epidemiol. 2003; 10(1): 3-13. PMid:12607154. http://dx.doi.org/10.1076/opep.10 .1 .3 .13773

[5] Bourne RA, Stevens GA, White RA, et al. Causes of vision loss worldwide, 1990-2010: a systematic analysis. The Lancet Global Health. 2013; 1(6): 39-349. http://dx.doi.org/10.1016/S22 14-109X (13) 70113-X

[6] Owsley C, McGwin G, Scille K, et al. The Visual Status of Older Persons Residing in Nursing Homes. Arch Ophthalmol. 2007; 125(7) 925-930. PMid:17620572. http://dx.doi .org/10.1001/archo pht.125.7.925

[7] Brouwer D, Sadlo G, Winding K, et al. Limitations in mobility: experiences of visually impaired older people. British Journal of Occupational Therapy. 2008; 71(10): 414-421. http://dx.doi.o $\mathrm{rg} / 10.1177 / 030802260807101003$

[8] Aarts MPJ, Westerlaken AC. Field study of visual and biological light conditions of independently-living elderly people. Gerontechnology. 2005; 4(3): 141-152. http://gerontechnology.info/index.p $\mathrm{hp} /$ journal/article/view/gt.2005.04.03.004.00

[9] De Lepeleire J, Bouwen A, De Coninck L, et al. Insufficient lighting in nursing homes. Journal of the American Medical Directors Association. 2007; 8(5): 314-317. PMid:17570310. http: //dx.doi.org/10.1016/j.jamda.2007.01.003
[10] WHO, World Health Organisation. Towards a Common Language for Functioning, Disability and Health, World Health Organization, Geneva; 2002. ICF, International Classification of Functioning Disability and Health 2002; Geneva. http: //www . who. int/cl assifications/icf/training/icfbeginnersguide.pdf [accessed 18 December 2015]

[11] Joseph A. Health Promotion by Design in Long-Term Care Settings. The Center for Health Design. [www.healthdesign.org]. 2006 https://www.healthdesign.org/sites/default/files/H ealth $\% 20$ Promotion $\% 20$ by $\% 20$ Design $\% 20$ in $\% 20$ LTC $\% 20$ Setti ngs_0.pdf

[12] Bouma H, Weale RA, McCreadiel C. Technological environments for visual independence in later years. Gerontechnology. 2006; 5(4): 187 195. http://gerontechnology. info/index.php/journal/a rticle/view/gt.2006.05.04.001.00

[13] Boyce PR. Lighting for the elderly. Technology and Disability. 2003; 15(3): 165-180. http://content.iospress.com/articles/te chnology-and-disability/tad00131

[14] Evans BJW, Sawyerr H, Jessa Z. A pilot study of lighting and low vision in older people. Lighting Research and Technology. 2009; 0: 1-17. http://lrt. sagepub. com/content/early/2009/07/ 22/1477153509339240.full.pdf+html

[15] Sinoo MM, van Tilborg M, Schols MGA, et al. Age Related Visual Pathologies among Nursing Home Residents: An Evaluation of Light Conditions and Recording in Client Files. World Journal of Social Science Research. 2014; 1(2): 27-42. http://www. scholink. org /ojs/index.php/wjssr/article/view/257

[16] Sinoo MM, Kort HSM, Duijnstee MSH. Visual functioning in nursing home residents: information in client records. Journal of Clinical Nursing. 2012; 21: 913-1921. http://onlinelibrary.wiley . com/doi/10.1111/j.1365-2702.2012.04128.x/epdf

[17] Marianne Sinoo and Helianthe Kort, Development of the Environmental Observation Scale for the Visual Impaired. Proceedings AAATE. September 2015. p. 423-427. http: //www . aaate2015. eu/wp-c ontent/uploads/2015/09/AAATE_booklet_web.pdf

[18] Polit DF, Beck CT. Essentials of nursing research: method, appraisal and utilization. New York: Lippincott; 2006a. 6th ed

[19] Polit DF, Beck CT. The Content Validity Index: are you sure you know what's being reported? Critique and recommendations. Re- 
search in Nursing \& Health. 2006b; 29: 489-497. http://online library.wiley.com/doi/10.1002/nur.20147/epdf

[20] Polit DF, Beck CT, Owen SV. Is the CVI an Acceptable Indicator of Content Validity? Appraisal and recommendations. Research in Nursing and Health. 2007; 30: 459-467. http: //onlinelibrary . wiley.com/doi/10.1002/nur.20199/epdf

[21] Lynn MR. Determination and quantification of content validity. Nursing Research. 1986; 35(6): 382-385. http://journals.1ww . com/nursingresearchonline/Citation/1986/11000/Det ermination_and_Quantification_0f_Content.17.aspx

[22] Rousseau J, Potvin L, Dutil E, et al. A critical review of assessment tools related to home adaptation issues. Occupational Therapy in Health Care. 2002; 14(3/4): 93-104. http://www.tandfonline. com/doi/abs/10.1080/J003v14n03_06
[23] Carnigan M, Rousseau J, Couturier JA. Content validity of a homebased person-environment interaction assessment tool for visually impaired adults. Journal of Rehabilitation Research \& Development. 2008; 45(7): 1037-1052. http://dx.doi.org/10.1682/JRRD. 2007.10 .0158

[24] Lewis A, Torrington J. Extra-care housing for people with sight loss:lighting and design. Lighting Research and Technology. 2012; 0: 1-17. http://lrt. sagepub. com/content/45/3/345.full. pdf + html

[25] Legood R, Scuffham P, Cryer C. Are we blind to injuries in the visually impaired? A review of the literature. Injury Prevention. 2002; 8: 155-160. http://injuryprevention. bmj.com/search?fu lltext $=$ legood\&submit $=$ es $\& x=0 \& y=0$ 